\title{
Fate of paralytic shellfish poisoning toxins ingested by the copepod Acartia clausi
}

\author{
Cástor Guisande*, Máximo Frangópulos, Ylenia Carotenuto**, Isabel Maneiro, \\ Isabel Riveiro, Alba Ruth Vergara
}

Facultad de Ciencias del Mar, Universidad de Vigo, Lagoas-Marcosende, 36200 Vigo, Spain

\begin{abstract}
The fate of paralytic shellfish poisoning (PSP) toxins ingested by the copepod Acartia clausi was studied in unialgal and mixed cultures of the toxic dinoflagellate Alexandrium minutum and the non-toxic dinoflagellate Prorocentrum micans. Acartia clausi fed actively on Alexandrium minutum, but feeding pressure diminished over time. This reduced feeding upon toxic phytoplankton seems to be due to behavioural rejection, since feeding pressure on the non-toxic dinoflagellate did not diminish over time. The assimilation efficiency of toxins ingested by copepods was $3.8 \%$. Some of these toxins assimilated by copepods were redirected to the eggs, but the daily total toxin output in the eggs was only $0.98 \%$ of the daily toxins assimilated by the copepods. This small amount of toxins in the eggs had no effect on the fate of the toxins in the copepods, but did affect copepod reproductive success, since reduced egg hatching was observed with increasing toxin accumulation in the copepod tissues. The amount of toxins daily excreted in the pellets was only $2.26 \%$ of the daily amount of toxins assimilated by the copepods. However, the detoxification rate of PSP toxins by the copepods was $0.586 \mathrm{~d}^{-1}$. Therefore, toxins were either transformed and excreted as other compounds in faecal pellets and/or were eliminated through excretion in dissolved form. A model showed that the copepods accumulated PSP toxins through dietary incorporation, but excreted them after several days. Copepods accumulate toxins up to a threshold without any negative effect on fecundity, but above this threshold, they require a higher amount of food to achieve the same egg production rate.
\end{abstract}

KEY WORDS: Copepods $\cdot$ Toxins $\cdot$ PSP $\cdot$ Toxin fate $\cdot$ Ingestion $\cdot$ Toxin accumulation $\cdot$ Detoxification Resale or republication not permitted without written consent of the publisher

\section{INTRODUCTION}

Smayda (1997) suggested that toxin production by some dinoflagellates species could be an adaptation evolved to offset the ecological disadvantage of those dinoflagellates with low nutrient affinity. He showed that the nutrient uptake affinity for $\mathrm{NH}_{4}^{-}, \mathrm{NO}_{3}^{-}$and $\mathrm{PO}_{4}^{3-}$ in dinoflagellates is lower than in diatoms, and hence diatoms would be expected to outcompete dinoflagellates under low nutrient conditions. Other studies have also shown that toxic dinoflagellates are poor competitors compared to Prymnesiophyceae (Riegman et al. 1996) and even to non-toxic dinoflagellates (Cannon

\footnotetext{
*E-mail: castor@uvigo.es

** Present address: Stazione Zoologica 'A. Dohrn', Villa Comunale, 80121 Naples, Italy
}

1996). Guisande et al. (2002) showed that the copepod Acartia clausi fed mainly on Alexandrium minutum when the toxin content per cell of the latter was low, but with increasing toxin content per cell $A$. minutum (with decreasing $\mathrm{PO}_{4}^{3-}$ concentrations), feeding pressure was redirected to the non-toxic dinoflagellate Prorocentrum micans. Therefore, in addition to feeding avoidance, an ecological advantage of toxin production by toxic dinoflagellates is probably to offset interspecific competition by redirecting grazing pressure onto non-toxic phytoplankton species that are potential competitors (Smayda 1997, Guisande et al. 2002).

Both feeding avoidance and the strategy of producing toxins as a mechanism to enhance interspecific competition under nutrient limitation implies that toxins must act as feeding deterrents. However, many studies have shown that grazers ingest toxic algae (see 
Turner \& Tester 1997). Enhanced toxin production is observed in PSP producers under P limitation (Boyer et al. 1987, Anderson et al. 1990, Guisande et al. 2002) and in other marine toxic phytoplankton species which produce toxins with a low elemental $\mathrm{N}$ and $\mathrm{P}$ composition under both $\mathrm{N}$ and $\mathrm{P}$ limitation (Johansson \& Granéli 1999). This indicates that some dinoflagellates species usually produce high amount of toxins under nutrient limitation. If zooplankton species cannot detect cells with low toxin content, then under non-limiting nutrient conditions grazers could ingest low cell-toxicity phytoplankton species. Moreover, the presence of toxins does not cause toxic dinoflagellates to avoid or to be selected against by grazer species, because the degree of selection by grazers seems to be a function of the grazer's ability to tolerate PSP toxin ingestion (Teegarden 1999). Finally, it has been suggested that a low frequency of encounter with toxic cells by zooplankton may be insufficient to trigger a selective feeding response (Teegarden et al. 2001). Therefore, the incapacity of grazers to detect toxins due to low cellular toxicity, the facts that grazers are not affected by moderate PSP toxin ingestion, and/or chemical deterrence is concentration-dependent, means that zooplankton species could ingest toxic phytoplankton species and act as potential vectors of toxins in the pelagic food web.

Copepods are one of the zooplankton groups that prey on toxic dinoflagellates (see Turner \& Tester 1997). Through ingestion of toxic phytoplankton, copepods have been observed to accumulate toxins (White 1981, Boyer et al. 1985, Turrif et al. 1995, Teegarden \& Cembella 1996, Frangópulos et al. 2000, Guisande et al. 2002) and transfer them to higher trophic levels (White 1981). Copepods may also transfer toxins to their faecal pellets and/or eggs, or play an important role in toxin-detoxification and, hence, in toxin removal from the marine food web. Therefore, the feeding interaction between copepods and toxic dinoflagellates could be of importance to the fate of dinoflagellate toxins in the food web.

The toxic dinoflagellate Alexandrium minutum and the copepod Acartia clausi often co-occur in Ría de Vigo (Spain). The aim was to study the fate of PSP toxins produced by Alexandrium minutum that are ingested by the copepods.

\section{MATERIALS AND METHODS}

Algal species. The non-axenic dinoflagellate strains of Alexandrium minutum (A1 IV) (mean \pm SE cell diameter $22.0 \pm 0.61 \mu \mathrm{m}, \mathrm{n}=31$ ) and Prorocentrum micans (mean \pm SE cell diameter $32.5 \pm 0.94 \mu \mathrm{m}$, $\mathrm{n}=31$ ) used in this study were isolated from the Galician rías and came from long-established populations cultured in the Instituto Español de Oceanografía (Vigo).
The diameter of the algal species ensures $100 \%$ filtering efficiency of Acartia clausi feeding on Alexandrium minutum and $P$. micans (Donaghay \& Small 1979). A. minutum is a toxic strain that only contains Gonyautoxins 1, 2, 3 and 4 (GTX1 to 4) (Franco et al. 1994). The carbon and nitrogen content of the phytoplankton species was determined from subsamples filtered on pre-combusted GF/F filters at low pressure, dried at $70^{\circ} \mathrm{C}$ and combusted in a Fisons EA-1108. Sulphanilamide was used as the standard. The pg $\mathrm{C}$ and pg $\mathrm{N}$ contents (mean $\pm \mathrm{SE}$ ) per cell for A. minutum were $745.4 \pm 22.5$ and $184.4 \pm 5.7$, respectively, and for P. micans $1608.2 \pm 85.8$ and $355.3 \pm 19.3$, respectively.

Zooplankton collection. Zooplankton were collected by vertically integrated tows from a depth of $20 \mathrm{~m}$ to the surface, at a field station $39 \mathrm{~m}$ deep in Ría de Vigo, Spain $\left(42^{\circ} 13.3^{\prime} N, 8^{\circ} 47.7^{\prime} \mathrm{W}\right)$. Samples were transported within $2 \mathrm{~h}$ of collection to the laboratory, and adult Acartia clausi were sorted out for the experiments.

Experimental design. From the sample collected in the field, 1400 adults of Acartia clausi were sorted and 2 individuals were transferred to $25 \mathrm{ml}$ beakers containing the various experimental food concentrations. Except for 1 case, in which Prorocentrum micans alone was used, the beakers contained both $A$. clausi and $P$. micans. In all experimental food concentrations, we tried to keep the abundance of $P$. micans constant at around 100 cells $\mathrm{ml}^{-1}$, whereas the concentrations of Alexandrium minutum were 0 (60 replicates), 500 (160 replicates), 1000 (160 replicates), 1500 (160 replicates) and 2000 (160 replicates) cells $\mathrm{ml}^{-1}$. The carbon concentration in all experimental food concentrations including $A$. minutum was high enough to ensure that potential selection was not affected by possible food limitation, which might constrain grazers to consume less palatable prey (Teegarden 1999). The culture medium was prepared with aged natural sea-water (salinity 33.6\%) filtered through GF/F Whatman filters and autoclaved. Copepods were kept at $15^{\circ} \mathrm{C}$ under a 12:12 h light:dark cycle. Each day, the copepods were transferred to fresh phytoplankton suspensions at the experimental concentration. Copepod mortality was lower than $6 \% \mathrm{~d}^{-1}$ in all experimental food concentrations. A replicate was not taken into account if any of the copepods died. Pellet production, egg production and hatching success were estimated daily. Cell abundance of A. minutum and P. micans, toxin content per cell, toxin content per copepod, toxin content per egg and ingestion rates were estimated on Days 1, 4, 6, and 8 of the experiment at all experimental food concentrations. After Day 8, all copepods were transferred to a food medium with only 100 cells $\mathrm{ml}^{-1}$ of $P$. micans, and the experiment was ended on Day 12. Copepod toxin content was daily analyzed from Days 8 to 12 to estimate toxin detoxification. 
Egg production, hatching and faecal pellet-production estimations. For each experimental food concentration, eggs and faecal pellets produced by 30 to 40 copepods were collected daily. The eggs and pellets produced by 7 to 10 copepods were pooled, so there were 4 replicates for each experimental food concentration every day. From each of these replicates, 200 eggs produced by the females were incubated for a further $48 \mathrm{~h}$ before fixation, and the hatched nauplii and the remaining unhatched eggs were subsequently counted. The remaining eggs were used to estimate egg toxin concentration, and the number of faecal pellets produced by the copepods were counted. The number of female copepods was counted to estimate egg production.

Grazing estimation. Between 10 and 15 replicates ( 2 copepods per $25 \mathrm{ml}$ beaker) were used to estimate the ingestion rates of Acartia clausi on Alexandrium minutum and Prorocentrum micans at each experimental food concentration. Ten replicate control containers and 5 initial containers without copepods were prepared simultaneously. Samples from the initial containers were preserved immediately at the start of the experiment. Grazing experiments were run for $24 \mathrm{~h}$ at the temperature and light conditions described above. Copepod mortality was checked after the $24 \mathrm{~h}$ incubation, and the samples were preserved with $4 \%$ formaldehyde for phytoplankton cell-counting with an inverted microscope. Cell densities were determined by counting $1 \mathrm{ml}$ in a Sedgewick-Rafter chamber. Frost's (1972) equations were used to calculate ingestion rates.

Toxin analysis. To estimate the cell toxin content of Alexandrium minutum, algal cells were collected on pre-combusted $13 \mathrm{~mm}$ GF/F Whatman filters and stored at $-30^{\circ} \mathrm{C}$ in ultracentrifuge plastic tubes and lyophilized; $500 \mu \mathrm{l}$ of $0.05 \mathrm{M}$ acetic acid was added to the lyophilized material, and the sample was homogenized using a pipette tip adapted to fit the shape of the vial. The sample was shaken followed by freezing twice. Finally, the extract was centrifuged twice at $4000 \mathrm{rpm}$ for $10 \mathrm{~min}$, after which $200 \mu \mathrm{l}$ of the supernatant was carefully collected with a Hamilton syringe, and stored at $-30^{\circ} \mathrm{C}$. To analyze the copepod toxin content, 15 copepods were transferred from each experimental food concentration to filtered seawater and, to make sure that toxins recently ingested were excreted, after 2 to $3 \mathrm{~h}$ copepods were transferred to distilled water and immediately collected with a known volume of distilled water $(\leq 40 \mu \mathrm{l})$. This experimental design allowed us to measure only the toxins accumulated by the copepods. The eggs and faecal pellets produced by females were transferred from each experimental food concentration to distilled water, and eggs and pellets were immediately collected with a known volume of distilled water $(\leq 500 \mu \mathrm{l})$. The eggs of all females from the same experimental food concentration were combined into 1 sample, and the final number of eggs in the samples from the various concentrations ranged between 674 and 1580. The same protocol was used for the faecal pellets, with the final number of pellets in the various samples ranging between 390 and 1640. Samples of copepods, eggs and pellets were stored at $-30^{\circ} \mathrm{C}$ in ultracentrifuge plastic tubes and lyophilized; $60 \mu \mathrm{l}$ of acetic acid $(0.05 \mathrm{M})$ was added to the lyophilized material followed by the same steps described above.

Analysis of the paralytic shellfish poisoning (PSP) toxins by high-performance liquid chromatography (HPLC) with fluorescence detection was performed following a modification of the method of Oshima et al. (1989), described by Franco \& Fernández (1993). Chromatographic profiles of Alexandrium minutum cells were determined by quadruplicate injections of $30 \mu \mathrm{l}$ of extracts (diluted with $0.05 \mathrm{M}$ acetic acid, as necessary). Chromatographic profiles of copepods and eggs were determined by injection of $30 \mu \mathrm{l}$ of the extracts. Toxins from the National Research Council of Canada (Halifax) were used as toxin standards.

The toxicity of Alexandrium minutum, in saxitoxin equivalents (STXeq), was calculated from the HPLC chromatograms. The toxin concentrations were multiplied by a toxin-specific conversion factor to yield toxicity. The specific toxicity conversion factors of the individuals toxins were adopted from Oshima (1995), based upon empirical mouse bioassay data determined using purified standards and assuming the conversion factor of 1 mouse unit $(\mathrm{MU})=0.23 \mu \mathrm{g}$ STXeq for the ddy mouse strain: 567.6 (GTX1), 205.2 (GTX2), 364.3 (GTX3) and 414.7 (GTX4).

\section{RESULTS}

Table 1 shows the specific toxic composition and total toxin content per cell for Alexandrium minutum. There were significant differences in total toxin con-

Table 1. Alexandrium minutum. Specific toxin composition of gonyautoxins (GTX1-4, fmol cell ${ }^{-1}$ ) and total toxin per cell (combined GTX1, GTX2, GTX3 and GTX4, fmol cell ${ }^{-1}$ ) during the experiment. Values are means $\pm \mathrm{SE}$

\begin{tabular}{|c|c|c|c|c|c|}
\hline Day & GTX4 & GTX1 & GTX3 & GTX2 & Total toxin \\
\hline 1 & $2.39 \pm 0.06$ & $0.23 \pm 0.03$ & $0.13 \pm 0.01$ & $0.03 \pm 0.00$ & $2.79 \pm 0.08$ \\
\hline 4 & $1.76 \pm 0.21$ & $0.26 \pm 0.02$ & $0.09 \pm 0.01$ & $0.03 \pm 0.00$ & $2.14 \pm 0.24$ \\
\hline 6 & $1.93 \pm 0.02$ & $0.26 \pm 0.01$ & $0.06 \pm 0.00$ & $0.02 \pm 0.00$ & $2.27 \pm 0.03$ \\
\hline 8 & $1.34 \pm 0.05$ & $0.13 \pm 0.01$ & $0.04 \pm 0.00$ & $0.01 \pm 0.00$ & $1.52 \pm 0.05$ \\
\hline
\end{tabular}




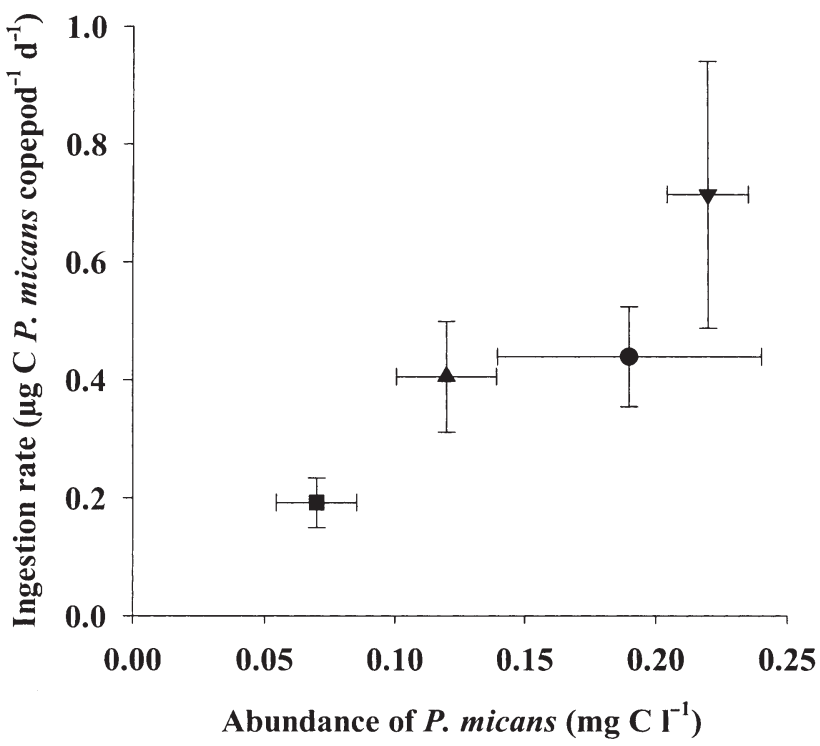

Fig. 1. Acartia clausi. Ingestion of Prorocentrum micans as a function of abundance of $P$. micans on Days $1(\boldsymbol{\nabla}), 4(\mathbf{\Delta}), 6(\bullet$ and $8(\square)$. All data are means $\pm \mathrm{SE}$

tent per cell over the course of the experiment (ANOVA, $F_{3,11}=14.3, \mathrm{p}<0.001$ ), and hence the toxin content per cell for each experimental day was used to estimate toxins ingested by copepods. The strain of A. minutum used in this study is at the low end of the toxicity range observed for species of the genus Alexandrium (Chang et al. 1997).

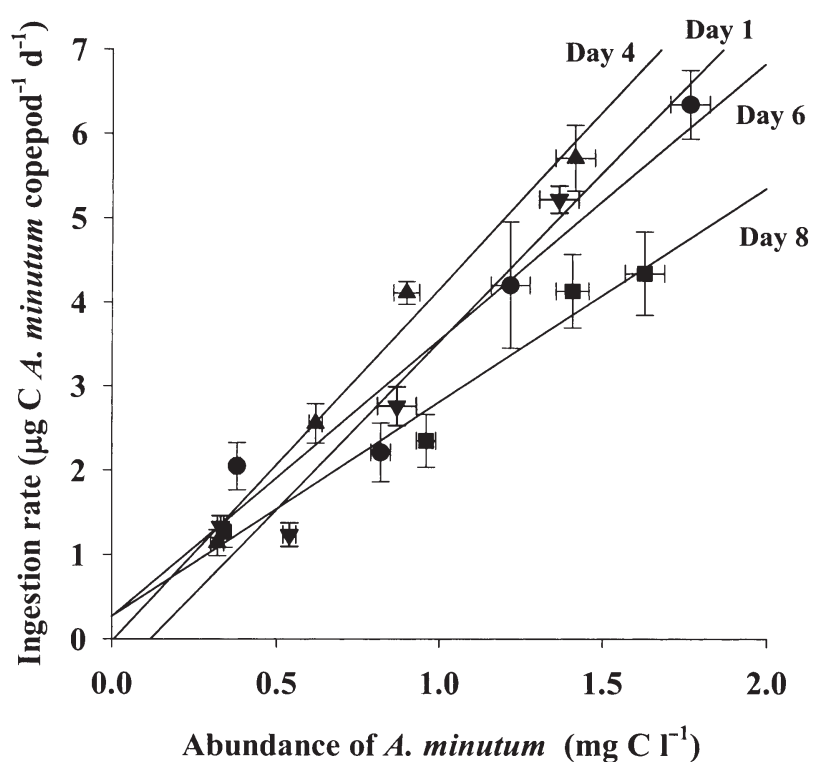

Fig. 2. Acartia clausi. Ingestion of Alexandrium minutum as a function of abundance of $A$. minutum. All data are means $\pm \mathrm{SE}$. Symbols as in Fig. 1
An analysis of covariance (ANCOVA), taking Prorocentrum micans abundance as covariable and time as a factor, showed that there was a significant relationship between ingestion rate of Acartia clausi on $P$. micans and abundance of $P$. micans (Fig. 1, $F_{1,226}=25.9$, $\mathrm{p}<0.001)$, but there were no differences in the ingestion rate of $A$. clausi on $P$. micans over the experiment $\left(F_{3,226}=1.2, \mathrm{p}=0.302\right)$.

An ANCOVA, taking abundance of Alexandrium minutum as covariable and time as a factor, showed that copepods also preyed actively on toxic dinoflagellates (Fig. 2, $F_{1,180}=217.1, \mathrm{p}<0.001$ ), but grazing pressure of Acartia clausi on Alexandrium minutum decreased over the experiment $\left(F_{3,180}=6.6, \mathrm{p}<0.001\right)$. A stepwise regression showed that ingestion rate of Acartia clausi on Alexandrium minutum ( $I$, in $\mu \mathrm{g} \mathrm{C}$ copepod ${ }^{-1} \mathrm{~d}^{-1}$ ) was significantly related to $A$. minutum abundance $\left(A\right.$, in $\left.\mathrm{mg} \mathrm{C}^{-1}\right)$ and time $(t$, in days $)\left(F_{2,13}=\right.$ 62.7, $\left.\mathrm{r}^{2}=0.91, \mathrm{p}<0.001\right)$ :

$$
I=0.314+3.375 A-0.000319 \mathrm{e}^{t}
$$

However, if only the 2 lower food concentrations are considered (500 and 1000 cells of Alexandrium minutum $\mathrm{ml}^{-1}$ ), an ANCOVA, taking abundance of A. minutum as covariable and time as a factor, shows that ingestion rate increased with increasing toxic dinoflagellate abundance $\left(F_{1,86}=10.1, \mathrm{p}=0.002\right)$, but grazing pressure of Acartia clausi on A. minutum did not change over the experiment $\left(F_{3,86}=1.8, \mathrm{p}=0.142\right)$. Ingestion rate of $A$. clausi on $A$. minutum $(I$, in $\mu \mathrm{g} \mathrm{C}$ copepod $^{-1} \mathrm{~d}^{-1}$ ) was significantly related to $A$. minutum abundance $\left(A\right.$, in $\left.\mathrm{mgC}^{-1}\right)\left(F_{1,6}=6.5, \mathrm{r}^{2}=0.52\right.$, $\mathrm{p}=0.043)$ :

$$
I=0.848+1.706 A
$$

Pellet production was higher in the experimental concentrations including Alexandrium minutum than in the experimental concentration with Prorocentrum micans alone (Fig. 3), confirming that $A$. minutum was ingested by Acartia clausi. In the experimental food concentration with A. minutum, an ANCOVA, taking the combined abundance of $A$. minutum and $P$. micans as covariable and time as a factor, showed that pellet production diminished from Days 3 to 8 (Fig. 3, $F_{5,89}=$ $8.9, \mathrm{p}<0.001)$, which confirms that the ingestion rate of $A$. clausi on A. minutum decreased over the experiment. Days 1 and 2 were not included because it is necessary to allow the copepods a few days to acclimate to the food concentrations.

The detoxification kinetic was described by the following equation $\left(F_{1,6}=138.5, \mathrm{r}^{2}=0.9, \mathrm{p}<0.001\right)$ :

$$
\mathrm{TC}_{t}=\mathrm{TC}_{t-1} \mathrm{e}^{-0.586 \mathrm{~d} t}
$$

where TC is toxin concentration in copepods (fmol copepod $^{-1}$ ) and $\mathrm{d} t$ is the difference between $t$ and $t-1$. 
The daily detoxification of PSP toxins in Acartia clausi obtained using Eq. (3) was $44.3 \%$ of total toxin concentration in the copepod's tissues.

An ANCOVA, taking toxins daily ingested by copepods as covariable and time as a factor, showed that

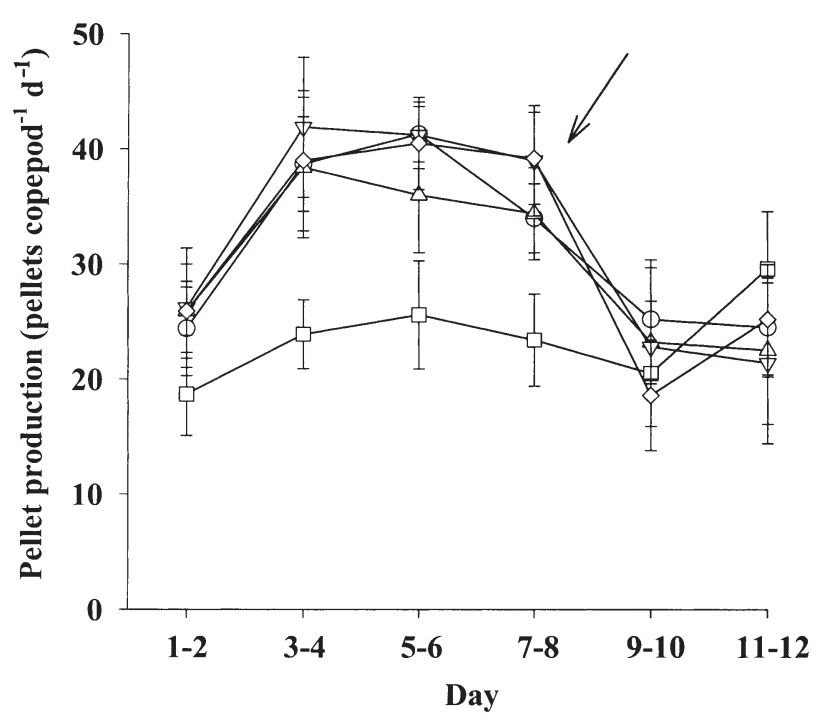

Fig. 3. Acartia clausi. Daily faecal pellet production during the experiment at the different experimental food concentrations. Cell concentrations of Prorocentrum micans were constant in all treatments $\left(\sim 100\right.$ cells ml $\left.{ }^{-1}\right)$, those of Alexandrium minutum differed. ( $\square$ ) P. micans alone; $(O),(\Delta),(\nabla),(\diamond)$ P. micans plus 500,1000, 1500 and 2000 cells $\mathrm{ml}^{-1}$ of $A$. minutum, respectively; arrow indicates transfer of copepods to food concentration with $P$. micans only. Data are means $( \pm \mathrm{SE})$ of $2 \mathrm{~d}$ each

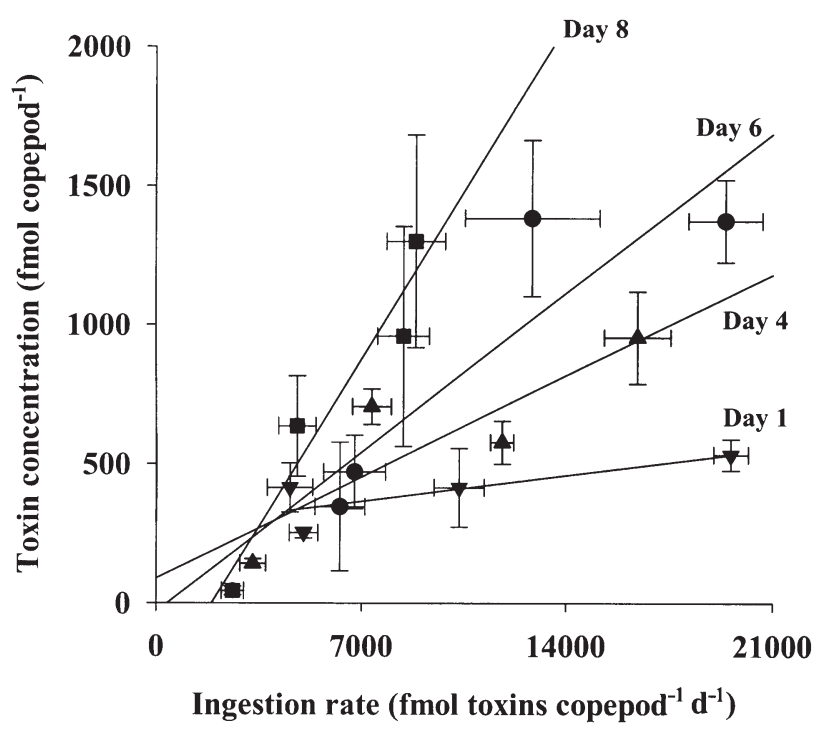

Fig. 4. Acartia clausi. Relationships between toxins ingested and toxin content per copepod during the experiment. All data are means \pm SE. Symbols as in Fig. 1 toxin content per copepod increased with increasing toxins ingested by the copepods (Fig. 4, $F_{1,41}=20.1$, $\mathrm{p}<0.001)$, and toxin content per copepod increased over the experiment $\left(F_{3,41}=84.5, \mathrm{p}=0.008\right)$.

An analysis of variance (ANOVA) showed that there were no significant differences in the percent molar composition of the isomers between copepods on Day 8 of the experiment and copepods on Day 12 (4 d detoxification): GTX4/GTX1， $F_{1,10}=1.8, \mathrm{p}=0.206$; GTX3/ GTX2, $F_{1,10}=0.6, p=0.46$ (Fig. 5); however, there were significant differences between the toxin profiles for Alexandrium minutum on Day 8 and those for the combined copepod data on Days 8 and 12: GTX4/ GTX1, $F_{1,14}=65.2, \mathrm{p}<0.001 ;$ GTX3/GTX2, $F_{1,14}=43.0$, $\mathrm{p}<0.001$.

Toxins were detected in the faecal pellets. Fig. 6 indicates a relationship between toxin content of the pellets (TP, fmol pellet ${ }^{-1}$ ) and the mean toxins ingested by the copepods over the experiment for each experimental food concentration (IT, fmol toxins copepod ${ }^{-1}$ $\left.\mathrm{d}^{-1}\right)\left(F_{1,2}=83.3, \mathrm{r}^{2}=0.98, \mathrm{p}=0.012\right)$ described by the following equation:

$$
\mathrm{TP}=-0.014+2.49810^{-5} \mathrm{IT}
$$

The toxin content of the eggs (TE, fmol egg ${ }^{-1}$ ) was also significantly related with the mean toxins ingested by the copepods over the experiment for each experimental food concentration (IT) (Fig. 7, $F_{1,2}=23.5$, $\left.\mathrm{r}^{2}=0.92, \mathrm{p}=0.04\right)$ :

$$
\mathrm{TE}=0.006+9.08710^{-6} \mathrm{IT}
$$

Fig. 8 shows egg production on Days 4, 6 and 8 of the experiment (days for which there is information

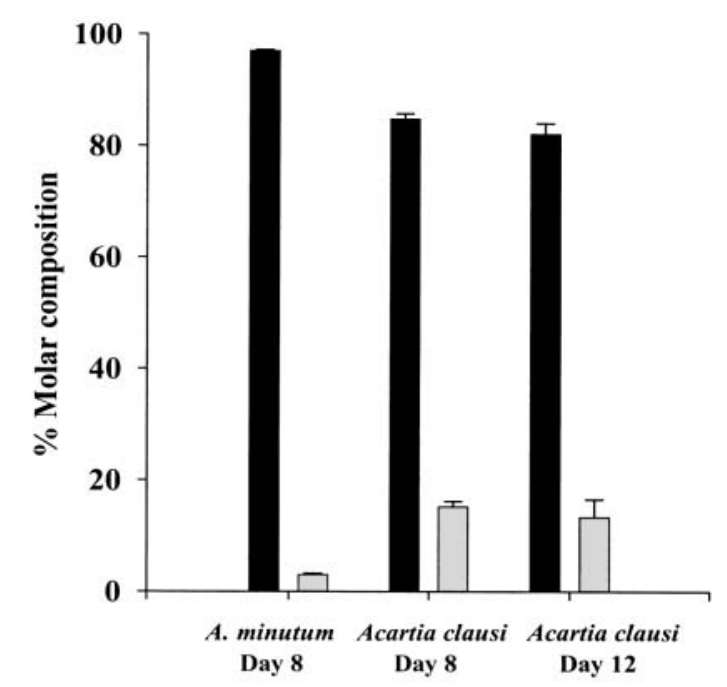

Fig. 5. Percent molar composition of combined isomers GTX4/GTX1 (black bars) and GTX3/GTX2 (shaded bars) of Alexandrium minutum on Day 8, and Acartia clausi on Days 8 and 12 


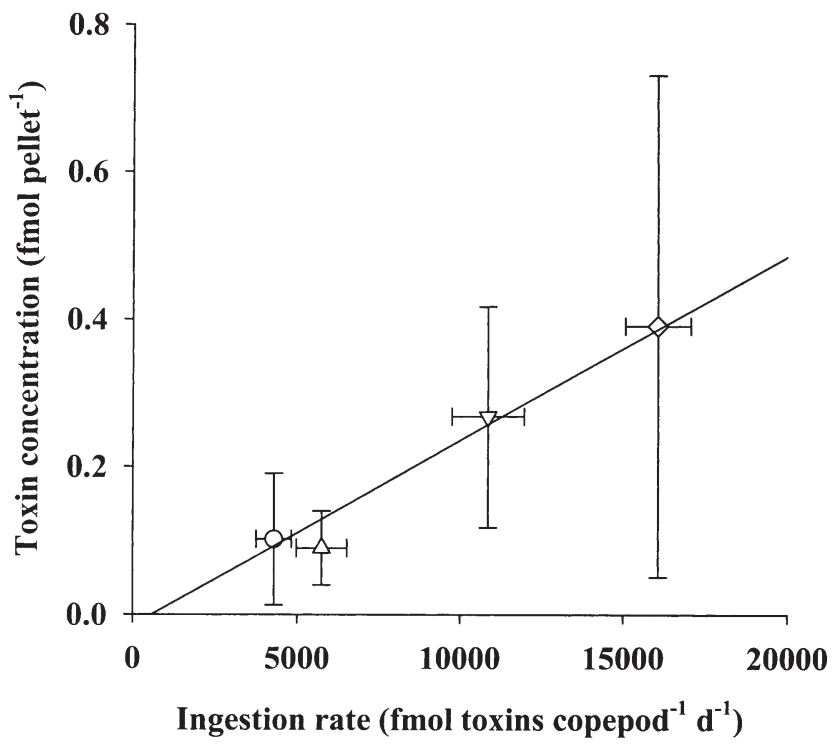

Fig. 6. Acartia clausi. Relationship between toxin content of faecal pellets and toxins ingested by copepods at each experimental concentration. All data are means \pm SE. Symbols as in

Fig. 3

about toxin content per copepod) as a function of food concentration and toxin concentration of the copepods. Day 1 is not included because, as mentioned earlier, it is necessary to allow the copepods a few days to acclimate to the food concentrations. An ANCOVA, taking food concentration (combined Alexandrium minutum and Prorocentrum micans abundances) as covariable and the toxin concentra-

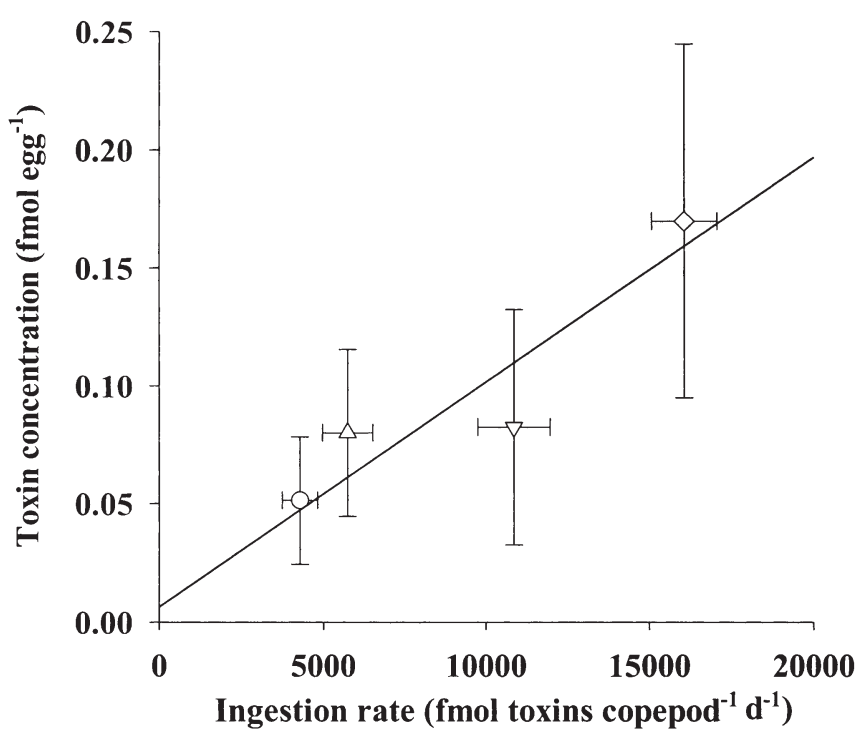

Fig. 7. Acartia clausi. Relationship between egg toxin content and toxins ingested by copepods at each experimental concentration. All data are means \pm SE. Symbols as in Fig. 3

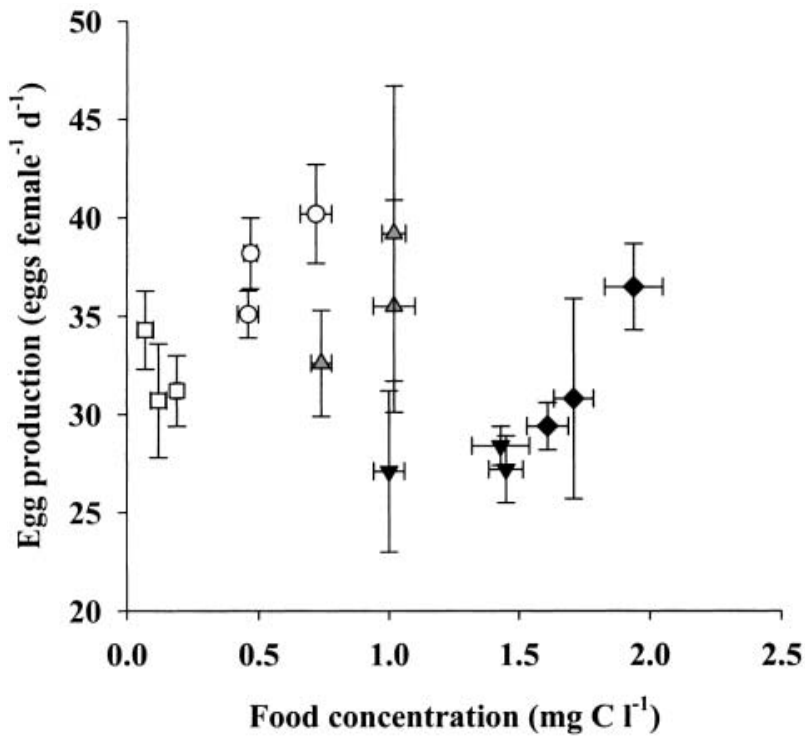

Fig. 8. Acartia clausi. Egg production as a function of food concentration (combined Alexandrium minutum and Prorocentrum micans) at each experimental food concentration. All data are means \pm SE. Toxin concentrations of the copepods (fmol copepod ${ }^{-1}$ ) were $<400$ (open symbols), between 400 and 800 (shaded symbols) and $>800$ (black symbols). Symbols as in Fig. 3

tion of the copepods as a factor, showed that (as expected) egg production increased with increasing food concentration $\left(F_{1,55}=11.1, \mathrm{p}=0.002\right)$, but that egg production decreased with increasing toxin content of the copepods $\left(F_{2,55}=10.2, \mathrm{p}<0.001\right)$. From Day 8 (when all copepods were transferred to a food

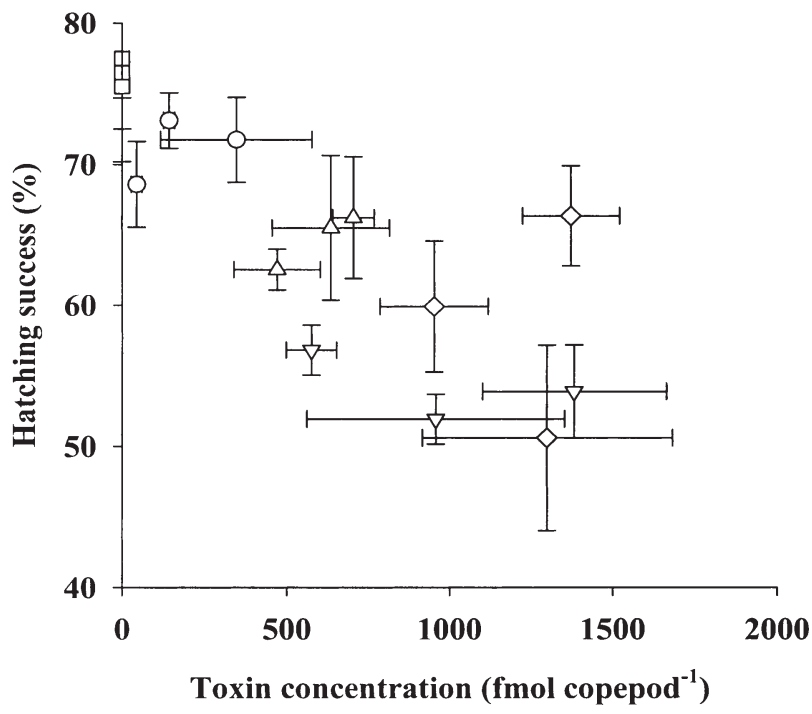

Fig. 9. Acartia clausi. Relationship between egg-hatching success and toxin concentration in the copepods at each experimental food concentration. All data are means \pm SE. Symbols as in Fig. 3 
Table 2. Acartia clausi. Daily toxin assimilated by copepods (fmol copepod ${ }^{-1} \mathrm{~d}^{-1}$, taking assimilation efficiency of toxin ingested as $3.8 \%$ ), daily toxin output (fmol copepod $\mathrm{d}^{-1} \mathrm{~d}^{-1}$ ) in eggs and faecal pellets during the experiment, and concentration in eggs and pellets as a percentage of the total toxins assimilated by the copepods, at each experimental food concentration (A. minutum: Alexandrium minutum, P. micans: Prorocentrum micans). Data are means $\pm \mathrm{SE}$

\begin{tabular}{|c|c|c|c|c|c|}
\hline \multirow{2}{*}{$\begin{array}{l}\text { Experimental } \\
\text { food conc. }\end{array}$} & \multirow{2}{*}{$\begin{array}{l}\text { Toxins assimilated } \\
\text { by copepods }\end{array}$} & \multicolumn{2}{|c|}{ Toxins in eggs } & \multicolumn{2}{|c|}{ Toxins in pellets } \\
\hline & & fmol & $(\%)$ & fmol & $(\%)$ \\
\hline \multicolumn{6}{|l|}{$\begin{array}{l}\text { A. minutum }\left(500 \text { cells ml }^{-1}\right) \\
\text { plus }\end{array}$} \\
\hline P. micans (500 cells $\mathrm{ml}^{-1}$ ) & $162.7 \pm 31.6$ & $1.93 \pm 0.07$ & $(1.19)$ & $3.87 \pm 0.17$ & $(2.38)$ \\
\hline \multicolumn{6}{|l|}{$\begin{array}{l}\text { A. minutum }\left(1000 \text { cells ml }^{-1}\right) \\
\text { plus }\end{array}$} \\
\hline P. micans (500 cells $\mathrm{ml}^{-1}$ ) & $218.4 \pm 26.1$ & $2.75 \pm 0.06$ & $(1.26)$ & $3.26 \pm 0.11$ & $(1.49)$ \\
\hline \multicolumn{6}{|c|}{$\begin{array}{l}\left.\text { A. minutum (1500 cells ml } \mathrm{m}^{-1}\right) \\
\text { plus }\end{array}$} \\
\hline P. micans (500 cells $\left.\mathrm{ml}^{-1}\right)$ & $412.8 \pm 36.5$ & $2.41 \pm 0.06$ & $(0.58)$ & $10.88 \pm 0.39$ & $(2.63)$ \\
\hline \multicolumn{6}{|l|}{$\begin{array}{l}\text { A. minutum }\left(2000 \text { cells } \mathrm{ml}^{-1}\right) \\
\text { plus }\end{array}$} \\
\hline P. micans $\left(500{\left.\text { cells } \mathrm{ml}^{-1}\right)}^{-1}\right.$ & $610.5 \pm 95.3$ & $5.38 \pm 0.13$ & $(0.88)$ & $15.45 \pm 0.96$ & $(2.53)$ \\
\hline
\end{tabular}

concentration with only P. micans) to Day 12 (end of the experiment), an ANCOVA, with time as covariable and the various experimental food concentrations as a factor, showed that there were no significant differences in egg production between copepods exposed to various experimental food concentrations $\left(F_{4,73}=1.8, \mathrm{p}=0.128\right)$.

Fig. 9 shows that egg hatching success was also affected by toxin concentration of copepods. A reduced egg hatching success was observed with increasing toxin concentration of the copepods (slope different from zero, $\left.F_{1,13}=24.1, \mathrm{r}^{2}=0.65, \mathrm{p}<0.001\right)$.

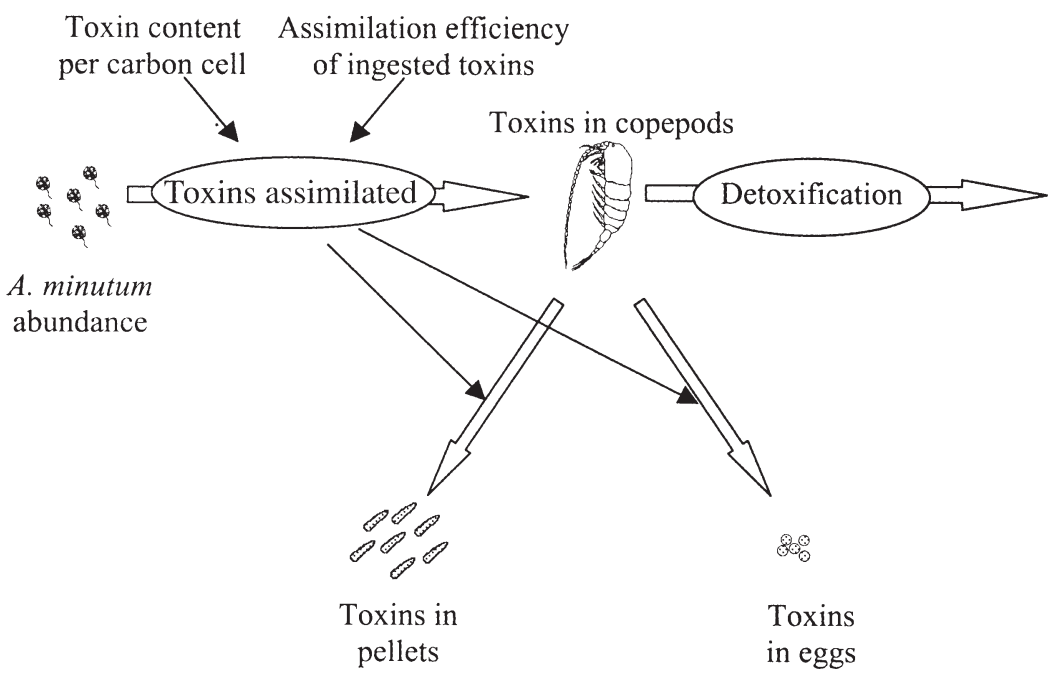

Fig. 10. Model of the fate of toxins produced by Alexandrium minutum that are ingested by Acartia clausi, and model specifications
From the toxin content per egg (Fig. 7) and the number of eggs daily produced by the females (Fig. 8), we estimated the daily toxin output in the eggs for each experimental food concentration (Table 2). The daily toxin output in the eggs as a percentage of the daily total toxins assimilated by the copepods was very low at all experimental food concentrations (Table 2), with a mean \pm SE of $0.98 \pm 0.15 \%$.

For each experimental food concentration, we also estimated the daily toxins output in the faecal pellets (Table 2) from the toxin content per pellet (Fig. 6) and the number of pellets daily produced by the females (Fig. 3). The daily toxin output in the pellets as a percentage of the daily total toxins assimilated by the copepods was also very low (Table 2), with a mean \pm SE of $2.26 \pm 0.26 \%$.

Using all the equations and data obtained in this study, we constructed a model with the software STELLA (2001: High Perfomance Systems) (Fig. 10). Table 3 shows the specifications of the model. The model used a mean toxin content per ng cell carbon of $2.96 \mathrm{fmol} \mathrm{ng} \mathrm{C}^{-1}$ (2.2 fmol cell $\left.{ }^{-1}\right)$. The concentrations of Alexandrium minutum used in the model were the means obtained at each experimental food concentration during the experiment: $1.54 \mathrm{mg} \mathrm{C} \mathrm{l}^{-1}$ for 2000 cells $\mathrm{ml}^{-1}$, $1.1 \mathrm{mgC}^{-1}$ for 1500 cells $\mathrm{ml}^{-1}$, $0.73 \mathrm{mgC} \mathrm{l}^{-1}$ for 1000 cells $\mathrm{ml}^{-1}$ and $0.34 \mathrm{mg} \mathrm{C}^{-1}$ for a food concentration 
Table 3. Specifications of the model

$\begin{array}{ll}\text { Integration method } & \begin{array}{l}\text { Euler's method } \\ \text { days }\end{array} \\ \text { Unit time } & 1 \mathrm{~d} \\ \mathrm{~d} t & 2.96 \mathrm{fmol} \mathrm{ng} \mathrm{C}^{-1} \\ \text { Toxin content carbon cell } & -1 \\ \text { Assimilation efficiency of toxins ingested } & 3.8 \% \\ \text { Alexandrium minutum abundance } & {\mathrm{mg} \mathrm{cell} \mathrm{C} \mathrm{l}^{-1}}^{-1} \mathrm{fmol} \mathrm{copepod}^{-1} \text { ) } \\ \text { Toxins assimilated } & \text { Toxin content carbon cell }{ }^{-1} \times 1000 \times \text { Eq. }(1) \times \text { Assimilation efficiency of toxins ingested } \\ \text { Model 1 } & \text { Toxin content carbon cell }{ }^{-1} \times 1000 \times \text { Eq. }(2) \times \text { Assimilation efficiency of toxins ingested } \\ \text { Model } 2 & \text { fmol copepod } \\ \text { Toxins in copepods } & 2.26 \% \text { of toxins assimilated } \\ \text { Toxins in faecal pellets } & 0.98 \% \text { of toxins assimilated } \\ \text { Toxins in eggs } & \text { Eq. }(3)\left(\mathrm{d}^{-1}\right) \\ \text { Detoxification } & \end{array}$

of 500 cells $\mathrm{ml}^{-1}$ of $A$. minutum. The assimilation efficiency of toxins ingested by the copepods that best reflects the results obtained in this study was 3.8\%. We ran 2 different models. Model 1 considered all experimental food concentrations (Eq. 1), and Model 2 considered only the 2 lowest food concentrations (500 and 1000 cells ml ${ }^{-1}$ ) of $A$. minutum (Eq. 2).

Fig. 11 shows that the toxin concentration observed in the copepods was similar to the values predicted by the model $\left(F_{1,14}=57.3, \mathrm{r}^{2}=0.81, \mathrm{p}<0.001\right.$, slope $=0.96$ and intercept $=24.6$ ). Fig. 12 shows the evolution of the copepod toxin concentration over time predicted by Model 1 for the highest (2000 cells $\mathrm{ml}^{-1}$ ) and lowest (500 cells ml ${ }^{-1}$ ) food concentrations of Alexandrium minutum used in this study, and by Model 2 for the food concentration of 500 cells ml ${ }^{-1}$ of A. minutum.

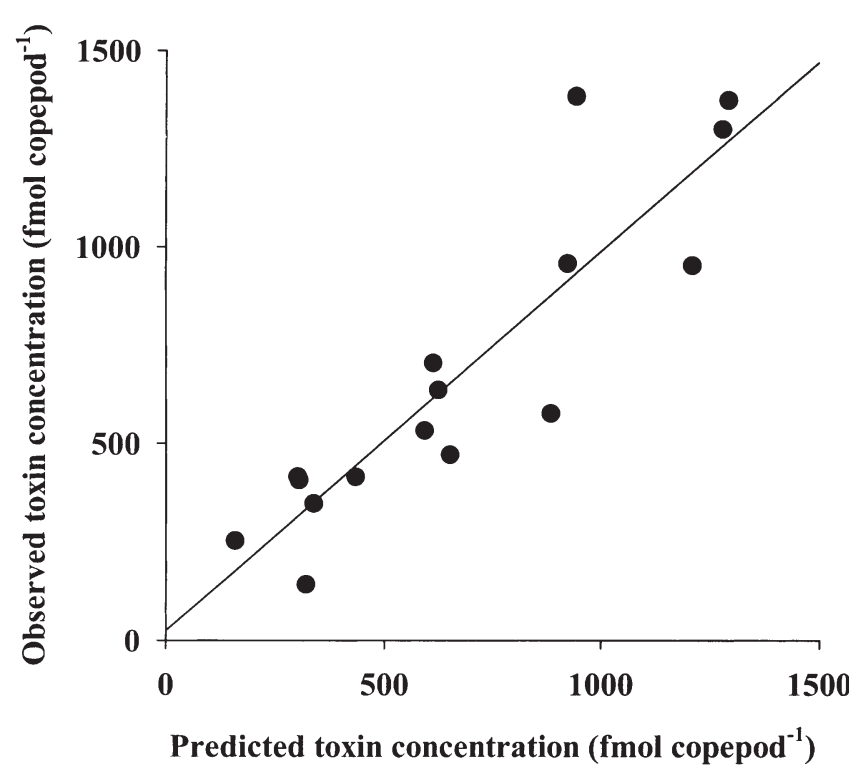

Fig. 11. Acartia clausi. Relationship between observed and predicted values obtained from the model of the toxin concentration of copepods

\section{DISCUSSION}

This study has shown that Acartia clausi fed on Alexandrium minutum, but that feeding pressure diminished over time. Reduced feeding upon toxic phytoplankton could be due to either behavioural rejection (Uye \& Takamatsu 1990, Teegarden 1999) or physiological incapacitation (Ives 1985, 1987, Huntley et al. 1986). Physiological incapacitation, as a reason for the lowered copepod grazing rates on toxic dinoflagellates, might be due to the interference of ingested toxins with feeding processes (Ives 1985). However, in our study, feeding pressure on the non-toxic dinoflagellate Prorocentrum micans did not diminish over the experiment, which suggests that ingestion of toxins did not affect the feeding capacity of the copepods. In

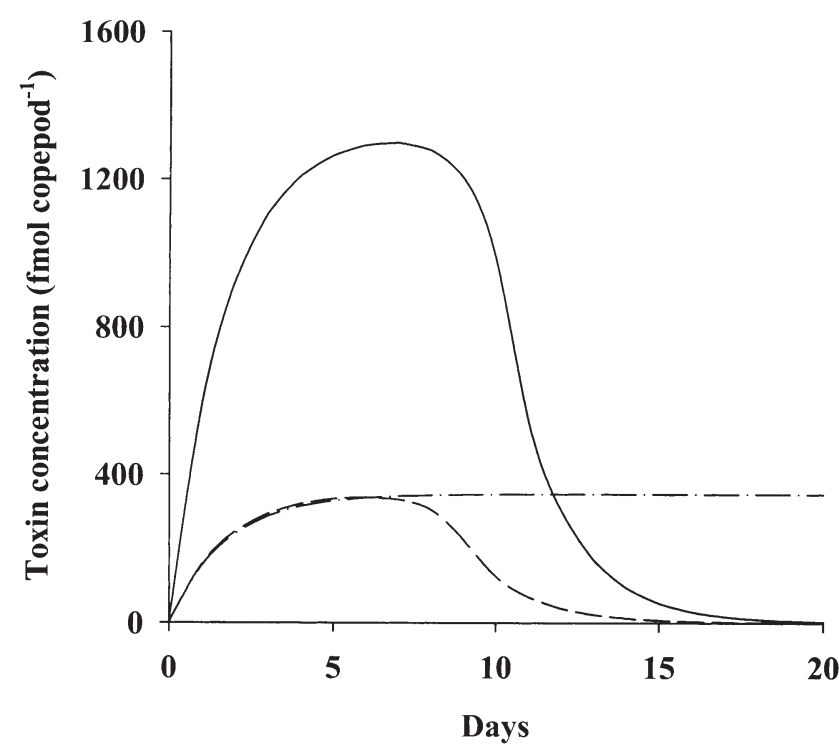

Fig. 12. Acartia clausi. Toxin concentration of copepods predicted by Model 1 at food concentration of 500 cells ml ${ }^{-1}$ (dashed line) and 2000 cells $\mathrm{ml}^{-1}$ (continuous line), and for Model 2 at a food concentration of 500 cells ml$^{-1}$ (dot-dashed line) of Alexandrium minutum 
fact, a study carried out with the same toxic strain of $A$. minutum, the non-toxic dinoflagellate $P$. micans and the copepod Acartia clausi showed that copepods fed mainly on Alexandrium minutum when the toxin content per cell was low, but as it increased, feeding pressure increased on $P$. micans and decreased on A. minutum (Guisande et al. 2002). Therefore, although it is not possible to reject the physiological incapacitation hypothesis, our findings support the idea that reduced grazing on toxic dinoflagellates is due to behavioural rejection of toxic phytoplankton species due to either chemosensory detection of noxious chemical cues or learned recognition by physically handling the cells. Moreover, our results support the idea that behavioural rejection arises through trial-and-error consumption of harmful phytoplankton that enables grazers to distinguish those species that should be avoided (Uye \& Takamatsu 1990), since at the beginning of the experiment, cells of $A$. minutum were ingested by the copepods.

There were differences in the toxin profiles between the toxins accumulated in the copepods and the cellular toxins of Alexandrium minutum (Fig. 5). The ratio GTX4+GTX1 to GTX3+GTX2 was 31.8 in A. minutum and 5.8 in the copepods. This lower GTX4+GTX1/ GTX3+GTX2 ratio for toxins accumulated in copepods than for the toxic dinoflagellates used as food has been observed in other copepod species (Boyer et al. 1985), and can be due to either differences in assimilation efficiencies and/or rates of detoxification. There was no significant difference in the percent molar composition of the isomers GTX4/GTX1 and GTX3/GTX2 between copepods on Days 8 and 12 (4 d of detoxification), indicating that the detoxification rate was the same for both isomers. Therefore, the difference in toxin ratios between the copepods and $A$. minutum seems to be due to differences in assimilation efficiencies.

The detoxification pattern observed in this study, an inverse exponential function, fits with the usual detoxification pattern observed in bivalves (Blanco et al. 1997, Lassus et al. 2000). There is no information available about detoxification rates in copepods that can be compared with our results. The detoxification rate of PSP toxins in Acartia clausi $\left(0.586 \mathrm{~d}^{-1}\right)$ is higher than the highest detoxification rate for PSP toxins observed in the mussel Mytilus galloprovincialis $\left(0.27 \mathrm{~d}^{-1}\right.$, Blanco et al. 1997). The detoxification rate in the mussel $M$. galloprovincialis is affected by environmental variables such as salinity and temperature (Blanco et al. 1997). Therefore, it is possible that the detoxification kinetic of A. clausi can also change in response to prevailing environmental conditions.

Despite copepod toxin detoxification, the low toxin retention efficiency of the toxins ingested $(3.8 \%)$ and the fact that an increasingly lower amount of toxins were daily ingested by the copepods during the course of the experiment, copepods did accumulate PSP toxins through dietary incorporation (Fig. 4). Such toxin accumulation has been reported before in copepod species (White 1981, Boyer et al. 1985, Turrif et al. 1995, Teegarden \& Cembella 1996, Frangópulos et al. 2000, Guisande et al. 2002). If we assume a mean $4.5 \mu \mathrm{g}$ dry wt per adult Acartia clausi (Guerrero \& Rodríguez 1997), the levels of PSP toxicity in A. clausi on Day 8 of the experiment were 12537 and $2398 \mu \mathrm{g}$ STXeq $100 \mathrm{~g}^{-1}$ dry wt for concentrations of 2000 and 500 cells ml $^{-1}$ Alexandrium minutum, respectively. This clearly exceeds the acceptable regulatory limit of toxins in shellfish for human consumption (80 $\mu \mathrm{g}$ STXeq $100 \mathrm{~g}^{-1}$ soft tissue). In Acartia tonsa and Eurytemora herdmani feeding on toxic Alexandrium spp., Teegarden \& Cembella (1996) also observed low retention efficiencies of ingested toxins but high levels of PSP toxins accumulated in the copepods in $12 \mathrm{~h}$ grazing trials of only $12 \mathrm{~h}$.

Faecal pellets produced by copepods represent an important input of material to the benthic community and could be an alternative mechanism of toxin transfer to bottom dwellers via sedimentation. Coprophagous organisms in the pelagic food web can also eat pellets and, hence, pellets produced by copepods could make toxins available to other organisms that do not feed on toxic dinoflagellates. As far we know, our study is the first report of toxins in pellets of copepods. However, the toxins in the faecal pellets represented only a small percentage $(2.26 \%)$ of the daily toxins assimilated by the copepods, and ranged between 0.4 and $2.3 \%$ of the total toxins accumulated in the copepod tissues. Daily detoxification in Acartia clausi accounted for $44.3 \%$ of the toxin concentration in the copepod tissues, and ranged between 42.9 and $237 \%$ of the daily toxins assimilated by the copepods. This means that the toxins were either transformed and excreted in the pellets as other compounds and/or eliminated as dissolved form. Hasegawa et al. (2001) showed that marine copepods release a significant part of the particle organic nitrogen ingested in the diet as dissolved nitrogen (up to $75 \%$ ). As PSP toxins are nitrogenous compounds (approximately $33 \%$ of PSP toxin weight is $\mathrm{N}$ ), toxins could be eliminated by copepods in a dissolved form. In our study, a higher amount of dissolved toxins was detected in the beakers with copepods that in those without copepods (C. Guisande pers. obs.). Gonyautoxins are intracellular compounds (Anderson \& Cheng 1988), and hence toxins produced by Alexandrium minutum cannot inhibit the growth of potential competitors. Excretion of toxins into the water by copepods could negatively affect non-toxic algae and would have important effects on interspecific competition among species constituting the phytoplankton community. 
Of the daily toxins assimilated by the copepods, a small percentage $(0.98 \%)$ was redirected to the eggs, and hence the amount of toxins in the eggs increased with increasing toxin ingestion by the copepods (Fig. 7). This small amount of toxins in the eggs does not affect the fate of the toxins in the copepods, but does have an important effect on the copepods' life cycle, since a reduced egg hatching success was observed with increasing toxin content of the copepods (Fig. 9). This is probably due to the negative effect of toxins accumulated in the eggs on egg hatching success (Frangópulos et al. 2000).

Our results explain why some studies have shown that copepod fecundity is negatively affected by ingestion of toxic dinoflagellates (Gill \& Harris 1987, Dutz 1998), whereas other studies have found no influence of toxic dinoflagellates on egg production (Frangópulos et al. 2000). Copepods can ingest and accumulate toxins up to a threshold without any negative effect on fecundity and, hence, egg production increases with increasing food concentration of the toxic algae. However, above this threshold a larger amount of food is necessary to achieve the same egg production rate. It seems that the effect of toxins on copepod fecundity is a 'yo-yo' process, because each time the toxin concentration of the copepods rises above a specific threshold, the ratio egg production/food concentration decreases (Fig. 8). This reduced egg production with increased toxin concentration of the tissues could be due to physiological incapacitation and/or enhanced energy expenditure of females to cope with the ingested toxins (Dutz 1998).

Our model predicted that after an initial toxin accumulation in the copepod tissues, copepods eliminate all the toxins by toxin detoxification and by reduced feeding pressure on toxic cells (Fig. 12). The model assumes that after several days the rejection efficiency is $100 \%$. However, although it is possible that copepods previously exposed to unpalatable food items learn to discriminate against harmful cells, such rejection would not be $100 \%$ efficient. Therefore (although at low rates), copepods would continue consuming toxic dinoflagellates and hence ingesting toxins. Moreover, if chemical deterrence is concentration-dependent (Teegarden et al. 2001), at low concentrations of toxic algae and/or because copepods are exposed to a plethora of different food items in their habitat, then low rates of encounter and ingestion could be insufficient to trigger a selective feeding response against toxic algae; hence, toxic dinoflagellates could be consumed at low rates by the copepods. In fact, we did not find significant differences between ingestion rates over the experiment at the 2 lower food concentrations (500 and 1000 cells of Alexandrium minutum $\mathrm{ml}^{-1}$ ), indicating that there was no feeding selection against toxic dinoflagellates at low $A$. minutum abundance. This corroborates the hypothesis that toxic dinoflagellates induce grazer avoidance only when their abundance results in high encounter frequency with the grazers, enabling the latter to learn to distinguish toxic dinoflagellates (Teegarden et al. 2001). Therefore, if rejection is not $100 \%$ efficient and/or chemical deterrence is concentration-dependent, copepods would continue feeding on toxic algae and would not excrete all the toxins.

Acknowledgements. This research was supported by the FATE project EVK3-CT2000-00055, a grant from the Chilean Government to M.F., an FPU grant to I.M., a grant from Fundación Provigo to I.R., and an AECI grant to A.R.V.

\section{LITERATURE CITED}

Anderson DM, Cheng PTO (1988) Intracellular localization of saxitoxins in the dinoflagellate Gonyaulax tamarensis. J Phycol 24:12-22

Anderson DM, Kullis DM, Sullivan JJ, Hall S, Lee C (1990) Dynamics and physiology of saxitoxin production by the dinoflagellates Alexandrium spp. Mar Biol 104:511-524

Blanco J, Moroño A, Franco J, Reyero MI (1997) PSP detoxification kinetics in the mussel Mytilus galloprovincialis. One- and two-compartment models and the effect of some environmental variables. Mar Ecol Prog Ser 158:165-175

Boyer GL, Sullivan JJ, Leblanc M, Anderson RJ (1985) The assimilation of PSP toxins by the copepod Tigriopus californicus from dietary Protogonyaulax catenella. In: Anderson DM, White AW, Baden DG (eds) Toxic dinoflagellates. Elsevier, New York, p 407-412

Boyer GL, Sullivan JJ, Andersen RJ, Harrison PJ, Taylor FJR (1987) Effects of nutrient limitation on toxic production and composition in the marine dinoflagellate Protogonyaulax tamarensis. Mar Biol 96:123-128

Cannon JA (1996) Competition between the dinoflagellates Alexandrium minutum and Prorocentrum micans in the Port River, South Australia. In: Yasumoto T, Oshima Y, Fukuyo Y (eds) Harmful algae. Proc 7th Int Conf Toxic Phytoplankton. Intergovernmental Oceanographic Commission (IOC), UNESCO, Rome, p 381-384

Chang FH, Anderson DM, Kulis DM, Till DG (1997) Toxin production of Alexandrium minutum (Dinophyceae) from the Bay of Plenty, New Zealand. Toxicon 35:393-409

Donaghay PL, Small LF (1979) Food selection capabilities of the estuarine copepod Acartia clausi. Mar Biol 52:137-146

Dutz J (1998) Repression of fecundity in the neritic copepod Acartia clausi exposed to the toxic dinoflagellate Alexandrium lusitanicum: relationship between feeding and egg production. Mar Ecol Prog Ser 175:97-107

Franco JM, Fernández P (1993) Separation of PSP toxins by reversed phase high performance liquid chromatography, with postcolumn reaction and fluorimetric detection. Chromatographia 35:613-620

Franco JM, Fernández P, Reguera B (1994) Toxin profiles of natural populations and cultures of Alexandrium minutum Halim. J Appl Phycol 6:275-279

Frangópulos M, Guisande C, Maneiro I, Riveiro I, Franco JM (2000) Short-term and long-term effects of the toxic dinoflagellate Alexandrium minutum on the copepod Acartia clausi. Mar Ecol Prog Ser 203:161-169 
Frost BW (1972) Effects of size and concentration of food particles on the feeding behaviour of the marine planktonic copepod Calanus pacificus. Limnol Oceanogr 17:805-815

Gill CW, Harris RP (1987) Behavioural responses of the copepods Calanus helgolandicus and Temora longicornis to dinoflagellate diets. J Mar Biol Assoc UK 67:785-801

Guerrero F, Rodríguez V (1997) Estimates of secondary production in a co-existent group of Acartia species (Copepoda, Calanoida). Crustaceana 70:584-593

Guisande C, Frangópulos M, Maneiro I, Vergara AR, Riveiro I (2002) Ecological advantages of toxin production by the dinoflagellate Alexandrium minutum under phosphorus limitation. Mar Ecol Prog Ser 225:169-176

Hasegawa T, Koike I, Mukai H (2001) Fate of food nitrogen in marine copepods. Mar Ecol Prog Ser 210:167-174

Huntley ME, Sykes P, Rohan S, Marin V (1986) Chemicallymediated rejection of dinoflagellate prey by the copepods Calanus pacificus and Paracalanus parvus: mechanism, occurrence and significance. Mar Ecol Prog Ser 28:105-120

Ives JD (1985) The relationship between Gonyaulax tamarensis cell toxin levels and copepod ingestion rates. In: Anderson DM, White AW, Baden DG (eds) Toxic dinoflagellates. Elsevier, New York, p 413-418

Ives JD (1987) Possible mechanisms underlying copepod grazing responses to levels of toxicity in red tide dinoflagellates. J Exp Mar Biol Ecol 112:131-145

Johansson N, Granéli E (1999) The influence of different N:P supply ratios on cell density, chemical composition and toxicity of Prymnesium parvum (Haptophyta) in semicontinuous cultures. J Exp Mar Biol Ecol 139:243-258

Lassus P, Bardouil M, Massselin P, Naviner M, Truquet P (2000) Comparative efficiencies of different non-toxic microalgal diets in detoxification of PSP-contaminated oysters (Crassostrea gigas Thunberg). J Nat Toxins 9:1-12

Oshima Y (1995) Post-column derivatization HPLC methods for paralytic shellfish poisons. In: Hallegraeff GM, Anderson DM, Cembella AD (eds) Manual on harmful marine

Editorial responsibility: Otto Kinne (Editor),

Oldendorf/Luhe, Germany microalgae. IOC Manual and guide no. 33. Intergovernmental Oceanographic Commission (IOC), UNESCO, Paris, p 81-94

Oshima Y, Sugino K, Yasumoto T (1989) Latest advances in HPLC analysis of paralytic shellfish toxins. In: Natori $\mathrm{S}$, Hashimoto K, Ueno Y (eds) Mycotoxins and phycotoxins. Elsevier, Amsterdam, p 319-326

Riegman R, de Boer M, de Senerpont Domis L (1996) Growth of harmful marine algae in multispecies cultures. J Plankton Res 18:1851-1866

Smayda TJ (1997) Harmful algal blooms: their ecophysiology and general relevance to phytoplankton blooms in the sea. Limnol Oceanogr 42:1137-1153

Teegarden GJ (1999) Copepod grazing selection and particle discrimination on the basis of PSP toxic content. Mar Ecol Prog Ser 181:163-176

Teegarden GJ, Cembella AD (1996) Grazing of toxic dinoflagellates, Alexandrium spp., by adult copepods of coastal Maine: implications for the fate of paralytic shellfish toxins in marine food webs. J Exp Mar Biol Ecol 196:145-176

Teegarden GJ, Campbell RG, Durbin EG (2001) Zooplankton feeding behavior and particle selection in natural plankton assemblages containing toxic Alexandrium spp. Mar Ecol Prog Ser 218:213-226

Turner JT, Tester PA (1997) Toxic marine phytoplankton, zooplankton grazers, and pelagic food webs. Limnol Oceanogr 42:1203-1214

Turriff N, Runge JA, Cembella AD (1995) Toxin accumulation and feeding behaviour of the planktonic copepod Calanus finmarchicus exposed to the red-tide dinoflagellate Alexandrium excavatum. Mar Biol 123:55-64

Uye S, Takamatsu K (1990) Feeding interactions between planktonic copepods and red-tide flagellates from Japanese coastal waters. Mar Ecol Prog Ser 59:97-107

White AW (1981) Marine zooplankton can accumulate and retain dinoflagellate toxins and cause fish kills. Limnol Oceanogr 26:103-109

Submitted: January 16, 2002; Accepted: April 25, 2002

Proofs received from author(s): August 22, 2002 